\title{
Overcoming Obstacles to Evolution Education: Why Bother Teaching Evolution in High School?
}

\author{
Louise S. Mead • Glenn Branch
}

Published online: 1 February 2011

(C) Springer Science+Business Media, LLC 2011

\begin{abstract}
Evolution is a foundational organizing principle of the life sciences, and yet people still argue that it should be taught only in college, urging that it's not necessary, too controversial, or too difficult to teach evolution in high school. Faced with such arguments, teachers and administrators need to have responses. Moreover, they need to teach evolution so that the coverage of evolution in the $\mathrm{K}-12$ curriculum reflects its central place in biology.
\end{abstract}

Keywords Evolution · High school biology

During a panel discussion following a recent screening of No Dinosaurs In Heaven (http://www.nodinosaursinheaven. org/), a new film about the creationism/evolution controversy, one of us was asked by someone in the audience, "Why even bother to teach evolution to high school students? Why not just wait until college?"

There is a certain specious appeal about the idea of deferring the teaching of evolution to college, which can be felt even by those who accept evolution. One might think that doing so would be harmless: teaching evolution at the high school level is not necessary; evolution is a complex concept that younger students do not need to learn. One might think that doing so would also be helpful, enabling teachers, students, and their communities to avoid needless controversy, of the sort that practically tore Dover,

L. S. Mead $(\bowtie) \cdot$ G. Branch

National Center for Science Education

PO Box 9477, Berkeley, CA 94709-0477, USA

e-mail:mead@ncse.com

Present Address:

L. S. Mead

BEACON Center for the Study of Evolution in Action,

1441 Biomedical and Physical Sciences Building,

Michigan State University

East Lansing, MI 48824, USA

email: 1smead@msu.edu
Pennsylvania, apart in 2004-2005 (Lebo 2008). One might even think, as the eminent microbiologist Carl Woese is reported to think, that the quality of evolution education at the high school level is so poor that it would be better to defer it to college (http://www.wired.com/wiredscience/ 2008/02/famed-microbiol).

We don't know why the gentleman who posed the question after the film screening thought that it might be appropriate to defer the teaching of evolution to college, so we don't know what specific response would have convinced him otherwise. But there are good responses to these three concerns, all centering on the crucial point that - as Theodosius Dobzhansky (1973) rightly stated - "nothing in biology makes sense except in the light of evolution." By providing a unifying principle for biology, evolution provides a powerful framework for investigating the living world, enabling us to develop models, frame theories, and test hypotheses.

Consider the tooth. Most mammals have teeth, but there are a few groups of mammals that do not have teeth (baleen whales, pangolins, giant and pygmy anteaters) or lack enamel on their teeth (two- and three-toed sloths, armadillos, aardvarks, and pygmy sperm whales). Without evolution, what is there to say about such a pattern? A description of the anatomy and ecology of these animals might be interesting, but it would not explain the pattern of toothfulness and toothlessness. But an evolutionary line of questioning enables us to frame and test specific hypotheses about the pattern. For example, given the presence of teeth in almost all mammalian groups, we hypothesize that the ancestors of mammals had teeth, and that teeth or the ability to synthesize enamel were subsequently lost in edentulous mammals. We can test this hypothesis by looking at the fossil record, where we find evidence that cynodonts, the ancestors of early mammals, had teeth (Hopson and Kitching 2001) - indeed, teeth differentiated by their functions, which are distinctively characteristic of mammals. In addition, because proteins are coded for by genes, we predict that the gene for enamelin, one of the two unique classes of proteins found in enamel, will be present in 
edentulous mammals, but in various states of decay because it is no longer functional. And indeed, Meredith et al. (2009) sequenced the enamelin gene (ENAM) in a range of mammals and found in every species lacking teeth or enamel (and only in these species), that the enamelin gene is nonfunctional, in various states of decay, due to the accumulation of frameshift mutations and/or stop codons.

Similar examples of the power of evolution can be found by examining the fusion of chromosome 2 in humans (http:// www.indiana.edu/ ensiweb/lessons/c.fus.les.html), the endosymbiotic theory of cell evolution (http://www.biology.iupui. edu/biocourses/n100/2k2endosymb.html), and the evolution of whales from terrestrial mammals (http://www.indiana. edu/ ensiweb/lessons/whale.ev.html), just to offer a few examples. Evolutionary biologists confirm every day the truth of Dobzhansky's observation that evolution makes sense of the "sundry facts" of biology. Correspondingly, not teaching students about evolutionary biology severely limits their ability to understand how the living world operates.

By the same token, not teaching students about evolutionary biology severely limits their ability to understand how evolution matters to us, as it increasingly does, in our daily lives. To take just a single example, recall Sarah Palin's disdain for research on fruit flies, expressed during her vice-presidential campaign of 2008 (http://www. youtube.com/watch?v=HCXqKEs68Xk). Palin may not understand the importance of basic fundamental research on model organisms such as Drosophila, but the connections among evolutionary biology, model organisms, and human public health and curative medicine are clear. Drosophila share at least $60 \%$ of their genes with humans, including various genes involved in Fragile X syndrome (Deshpande et al. 2006), Alzheimer's disease (McBride et al. 2010) and Parkinson's disease (Lessing and Bonini 2009). Basic genetic and molecular research, possible on Drosophila but ethically problematic and practically unfeasible on humans, informs our understanding of these diseases in humans. For additional examples of how model systems inform human biology, check out "A Fish of a Different Color" (http:// evolution.berkeley.edu/evolibrary/news/060201_zebrafish).

All of these considerations, of course, are - or at any rate ought to be-familiar to readers of Evolution: Education and Outreach, and it is clear how they help to answer the question under consideration, "Why even bother to teach evolution to high school students? Why not just wait until college?"

First, the central importance of evolution to the study of biology is a powerful reason to introduce students in high school to at least the rudiments of evolution. Even students who will not be attending college and pursuing further study in the life sciences nevertheless ought to understand evolution. In part, they ought to understand evolution for its own sake, as one of the greatest triumphs of modern science. As Stephen Jay Gould (1999) memorably wrote,
"Evolution is not a peripheral subject but the central organizing principle of all biological science. No one who has not read the Bible or the Bard can be considered educated in Western traditions; so no one ignorant of evolution can understand science." But there are pragmatic reasons, too: students should also understand evolution in order to be informed consumers, workers, and citizens in a world in which the biological sciences are increasingly important-for example, in agriculture, biotechnology, climate change, genomics, and medicine. ${ }^{1}$

Second, fear of controversy is not a good reason to skip teaching evolution, even if it is distressingly common (Berkman et al. 2008). The teaching of evolution is a standard part of the high school biology curriculum because evolution is included (at least to some degree) in all state science standards (Mead and Mates 2009), and evolution is included in the science standards because the scientific community — in agreement with Dobzhansky and Gouldregard understanding evolution as a central and crucial component of scientific literacy. Given the scientific and pedagogical necessity of teaching evolution, fear of controversy is not a reason to skip teaching evolution in high school—only a reason to teach it sensitively, in a way that minimizes controversy, as well as properly. A new teacher worried about the prospect of provoking controversy might want to research ways to teach evolution effectively in the presence of student resistance. A new book, Lee Meadows's The Missing Link: An Inquiry Approach for Teaching All Students About Evolution (2009), offers lessons to address common student misconceptions about various aspects of evolution (see http://ncse.com/news/2010/12/glimpsemissing-link-006359 for a brief description and excerpt).

Finally, there is no gainsaying the fact that some teachers fail to teach evolution well; indeed, about one in six omit human evolution altogether, and one in eight present creationism as a scientifically credible alternative, according to a national poll (Berkman et al. 2008). And university biology instructors frequently report the prevalence of elementary misconceptions about evolution in their students (see, e.g., Alters and Nelson 2002). ${ }^{2}$ Here again, though,

\footnotetext{
${ }^{1}$ Keep in mind, too, that creationists will continue to promote misunderstandings about evolution, regardless of what is taught in the public schools (and they begin young: in the on-line store of the young-earth creationist ministry Answers in Genesis, there is a category of books for children 2 to 4 years old!). To defer the teaching of evolution to college is, in effect, to grant the creationists the chance of being the primary expounders of evolution to those who do not pursue any higher education - about half of the population.

${ }^{2}$ Woese's concerns seem to go deeper still, since he complains that "what they pass on as evolution in high schools is nothing but repetitious trips that teachers don't understand. ... all that's there is teaching the same old pap for 150 years, modified by neo-Darwinists but not in any useful way." Then again, he seems to concede that the textbook treatments of the primate family tree-which, as noted by Berkman et al. (2008), often skipped — are probably adequate.
} 
the solution is not to stop the teaching of evolution at the high school level but to take steps to ensure that it is taught better there. At the pre-service level, aspiring science teachers need to be taught more about evolutionary biology and more about how to teach it effectively. At the in-service level, active science teachers need frequent and affordable opportunities to attend courses and workshops on evolution and related topics, ideally organized and coordinated at a national level (the annual NABT (National Association of Biology Teachers) Evolution Symposium, cosponsored by the American Institute of Biological Sciences and the National Evolutionary Synthesis Center, is a good model: http://www.nescent.org/media/NABT.php. Other useful information for organizing a workshop on teaching evolution is at http://www.ucmp.berkeley.edu/ncte/twb/). In light of recent work showing the benefits of research experiences for teachers (Silverstein et al. 2009), it would be encouraging also to see such experiences more available for both pre-service and in-service teachers.

Evolution is all around us. Evolutionary biology is the discipline that delineates our origins and the trajectory of our genealogy, illuminates why we have certain characteristics and not others, and sketches the contours of the future of our species. Evolution informs our agricultural practices, fisheries management, and medical treatments. Leaving evolution out of the high school biology curriculum is as unacceptable as leaving algebra out of the mathematics curriculum or the Civil Rights Movement out of the social studies curriculum. Evolution is the organizing principle of biology, the study of life, and should be taught, not only in high schools but also, at a suitably age-appropriate level, throughout the K-12 science curriculum - and certainly not deferred to college.

\section{References}

Alters BJ, Nelson CE. Teaching evolution in higher education. Evolution. 2002;56:1891-901.

Berkman MB, Pacheco JS, Plutzer E. Evolution and creationism in America's classrooms: a national portrait. PLoS Biol. 2008;6(5): e124.

Deshpande G, Calhoun G, Schedl P. The Drosophila Fragile X protein dFMR1 is required during early embryogenesis for pole cell formation and rapid nuclear division cycles. Genetics. 2006;174:1287-98.

Dobzhansky T. Nothing in biology makes sense except in the light of evolution. Am Biol Teach. 1973;35:125-9.

Gould SJ. Dorothy, it's really Oz: a pro-creationist decision in Kansas is more than a blow against Darwin. Time. 1999;154:59.

Hopson JA, Kitching JW. A probainognathian cynodont from South Africa and the phylogeny of non-mammalian cynodonts. Bull Mus Comp Zool. 2001;156:5-35.

Lebo L. The devil in Dover: an insider's story of dogma v. Darwin in small-town America. New York: New Press; 2008.

Lessing D, Bonini NM. Maintaining the brain: insight into human neurodegeneration from Drosophila melanogaster mutants. Nat Rev Genet. 2009;10:359-70.

McBride SMJ, Choi CH, Schoenfeld BP, Bell AJ, Liebelt DA, Ferreiro D, et al. Pharmacological and genetic reversal of agedependent cognitive deficits attributable to decreased presenilin function. J Neurosci. 2010;30:9510-22.

Mead LS, Mates A. Why science standards are important to a strong science curriculum and how states measure up. Evol Edu Outreach. 2009;2:359-71.

Meadows L. The missing link: an inquiry approach for teaching all students about evolution. Portsmouth (NH): Heinemann; 2009.

Meredith RW, Gatesy J, Murphy WJ, Ryder OA, Springer MS. Molecular decay of the tooth gene enamelin (ENAM) mirrors the loss of enamel in the fossil record of placental mammals. PLoS Genet. 2009;5(9):e1000634.

Silverstein SC, Dubner J, Miller J, Glied S, Loike JD. Teachers' participation in research programs improves their students' achievement in science. Science. 2009;326:440-2. 